apuntesuniversitarios.upeu.edu.pe

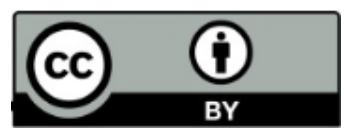

$C C-B Y$

Apuntes Universitarios, 2021: 11(4), octubre-diciembre

ISSN: 2304-0335 DOI:https://doi.org/au.v11i4.764

\title{
Investigando la traducción de modismos del persa al inglés según el modelo de Baker: Un estudio de caso
}

\author{
Investigating the translation of idioms from Persian into English based on Baker's model: \\ A case study
}

Mohaddeseh Omrani $^{1 \mathrm{a}}$, and Hossein Shams Hosseini ${ }^{\mathrm{b}}$

Department of Language Translation, Islamic Azad University, Quchan, Iran ${ }^{12}$

iD https://orcid.org/0000-0001-5405-9137

(iD) https://orcid.org/0000-0003-4340-2934²

Recibido: 08 de enero de 2021

Aceptado: 28 de junio de 2021

\section{Resumen}

El presente estudio evaluó las estrategias empleadas en la traducción de modismos persas al inglés.

El propósito era investigar cómo se puede identificar modismos en la novela persa El búho ciego de Sadegh Hedayat y traducirlos al inglés utilizando las estrategias de Baker. Además, se intentó comprender cuáles son las estrategias más utilizadas para traducir expresiones idiomáticas. El investigador recopiló 97 modismos persas y sus traducciones al inglés. Asimismo, se eligieron y examinaron cuatro estrategias que incluían: (1) usar un idioma de significado y forma similares; (2) usar un idioma de significado similar pero con forma diferente; (3) traducción por paráfrasis; y (4) traducción por omisión. El análisis de los datos ilustró que se usaron las siguientes estrategias para traducir expresiones idiomáticas en orden de frecuencia de uso: (1) usar un idioma de significado similar pero de forma diferente, (2) usar un idioma de significado y forma similar, (3) traducción por paráfrasis y (4) traducción por omisión. En síntesis, usar un idioma de significado similar pero de forma diferente fue la estrategia más utilizada para traducir modismos, y la traducción por omisión fue la estrategia menos utilizada.

Palabras clave: Sadegh Hedayat, El búho ciego, modismos, estrategias de traducción, textos literarios, calidad de la traducción, idioma persa

\footnotetext{
Abstract

${ }^{\mathrm{a} C}$ Correspondencia al autor:

Email: mohadesehomrani@yahoo.com

bEmail:H_shams_h@yahoo.com
}

This study assessed the strategies employed in translation of Persian idioms into English. The purpose was to investigate how we can identify idioms in the Persian novel The Blind Owl by Sadegh Hedayat and translate them into English through using Baker's strategies. Moreover, an 
attempt was made to understand what the most frequently used strategies are for translating idiomatic expressions. The researcher collected 97 Persian idioms and their English translations. Four strategies including (a) using an idiom of similar meaning and form (b), using an idiom of similar meaning but dissimilar form (c), translation by Paraphrase (d), and translation by omission were chosen and scrutinized. The analysis of the data illustrated that the following strategies were used in translating idiomatic expression in order of frequency of use: (1) using an idiom of similar meaning but dissimilar form, (2) using an idiom of similar meaning and form, (3) translation by paraphrase, and (4) translation by omission. Using an idiom of similar meaning but dissimilar form was the most frequently used strategy for translating idioms, and translation by omission was the least commonly used strategy.

Keywords: Sadegh Hedayat, The Blind Owl, Idioms, translation strategies, literary texts, translation quality, Persian language

\section{Introduction}

Translation is the transfer of the meaning of a word from one linguistic format to another. This complex and organized process of scientific and artistic works is presented in various literal, and free, etc. forms and is important. The complexity of this scientific activity is more in the case of the holy books. In connection with the Qur'an, translation is discussed in high importance. The English of this book is doubly important due to the special place of this language in the world and also the religious position of the speakers of this language. In the translation process, two factors, language and multilingual, play a role. The lexical range of languages and their inequality in semantic plurality are the first linguistic factor that plays a role in translation. The second linguistic factor that is effective in translation is the syntactic differences of different languages. The most important multilingual factor that affects translation It is ideology and ideological beliefs. The influence of the translator's ideology on translation, as a multilingual factor, is more unconscious and involuntary than conscious; However, sometimes the translator can consciously and voluntarily present a certain ideology in the form of translation (Anari \& Ebrahimi, 2020).

Fluent prose and accurate editing of the book, its arrangement of typographical errors and providing a number of good points about translation in some periods of Iranian history are some of the good features that the reader realizes when reading the book (Amini, 2021). However, it should always be borne in mind that the addition of such explanations should be in moderation and should not jeopardize the uniformity of the meaning of the text (Yaqub, 2014). Audiovisual translation indicates that research on oral description as one of the empowerment services and easy 
access to the media for the blind/visually impaired has increased significantly in many parts of the world (Taste \& Shafi'i, 2021). Due to the challenging nature of the metaphorical problem, so far various theories have been proposed in connection with translatability, non-translatability and various methods of metaphor translation, especially in relation to Quranic verses (Rezvantalab \& Dabbagh, 2021).

For the other hand, torture is a type of language borrowing in which a combination or terms of another language are decomposed and an equivalent is placed for each of its words and the phrase is translated into the language of the borrower. While acknowledging the existence of many strengths, it examines the weaknesses of translation (Ebrahimi, 2015). In this case, Moin-Darbari et al. (2016) conducted a study in that specifically considered the translation of terms as one of the linguistic elements of dependent culture.

In another study, Gholipour (2017) examines the most important mechanism for translating medical texts from English into Persian. His research focuses on translating equivalents for specialized medical terms in 15 English online articles into Persian, as well as the equivalents approved by the Academy of Persian Language and Literature Has been done.

To translate legal texts, one must consider various dimensions, which are: familiarity with the features of the language of the text, which includes aspects of its cultural and legal context, familiarity with the types of legal texts that have their own fields, familiarity with terms Special legal and vocabulary in this field and at the end familiarity with practical knowledge in this field (Stolez, 2013, 56). In translating legal texts, even conjunctions are important, so not paying attention to them can lead to incorrect translation of the text. For this reason, Bosica (2018) has addressed this issue and by comparing the letters "and" and "or" in the translation of the rules, the possibility of replacing these two letters and related issues has been mentioned. Numerous books and articles have been written about translating legal texts, the characteristics of translators, and the need for them to acquire skills. According to a survey conducted by Blidi (2018) with the help of professors and students of five universities in Oman, 58\% of translation problems of legal texts are due to lack of legal knowledge, $45 \%$ due to unfamiliarity with legal terms and $42 \%$ related to linguistic problems. This is one of the models of translation quality evaluation is the House model, which was introduced in 1997. His model was designed based on a comparative study of the source text and the target text, which leads to a qualitative evaluation of the translation and highlights heterogeneities or errors (Munday, 2012). The House model, he said, compares the linguistic, 
cultural and situational features of the source language and the target text. He describes his model as a principled comparison of two texts and an assessment of their relative similarity (House, 2015).

Also, translation is defined as the method of transferring meanings of utterances in one language to another (Catford, 1965). This author believes that translation is a process performed on language through which source language (SL) text is rendered into target language (TL) text. This means, translation has been considered as an exceptionally vital phenomenon by linguists and numerous definitions have been suggested by the scholars. It plays an important role in exchanging information and ideas among different languages. Hence, translators need to learn some skills, known as translation strategies, in order to convey correct, proper, and precise meanings to the target language.

For the other hand, one of the effective methods in semantic discussion is the analysis of words into units, in which, in order to achieve a precise and complete meaning, the words are broken down into their semantic components to reveal the meanings hidden in the layers of each word. This will eventually lead to a complete and clear translation of the text (Eghbali, 2020).

A major significance of the study is that the most critical issue for translating idioms is to find an appropriate equivalent in form and meaning in the target language. English language is exceptionally wealthy in utilizing idioms. Therefore, it is necessary to compare idioms in both languages. This helps readers be more interested in reading the translated books, novels, and poems. This study attempts to help translators find some appropriate strategies to cope with problems encountered while translating idioms and fixed expressions (Moon, 1988).

Since there are many idioms in Iranian culture which are quite unknown to the speakers of other languages, translators need to be careful about using a close equivalent in the target text. To sum up, the most important problem is related to the translation of different cultures and not simply the languages themselves. Therefore, the main objective of this study is to examine the strategies for translating idioms. To this end, Hedayat's well-known novel The Blind Owl was selected as the source text and the English translation as the target text. In addition, Baker's (1992) translation strategies were chosen as the theoretical framework of this study. After comparing the selected idioms with their English equivalents, appropriate strategies for translating them were identified and applied. 
This complex and organized process of scientific and artistic works is presented in various literal, free, etc. forms and is important. The complexity of this scientific activity is greater in the case of the holy books. In the translation process, two factors of language and metalanguage play a role. In semantic pluralism, they are the first linguistic factor that plays a role in translation. The second linguistic factor that is effective in translation is the syntactic differences of different languages. The most important multilingual factor that influences translation is ideology and ideological beliefs. The influence of the translator's ideology on translation, as a multilingual factor, is more unconscious and involuntary than conscious; However, sometimes a translator can consciously and voluntarily present a certain ideology in the form of a translation (Manafi \& Ebrahimi, 2020).

\section{Literature review}

\section{Idioms in translation}

Idiomatic statements are part of everyday communication, widely pragmatic in all type of communication, whether written or spoken. Idioms are usually defined as fixed expressions, with meaning that cannot be drawn from the meaning of their individual components (Aldahesh, 2013). Idiomatic expressions are part of all languages and people's everyday language uses. English linguistic, lexicographers, grammarian, and pedagogues have introduced various definitions for idiomatic expressions.

According to Kövecses (2010), there are two different points of view to define and explain an idiom: the translational view and the cognitive linguistic view. In the traditional view, idioms are considered particularly a matter of language, unrelated to any conceptual system, whereas in the cognitive linguistic realm, idioms are regarded as the outcome of our conceptual system and not merely a matter of language. The Longman Advanced Learner Dictionary (2009) defines idioms as "group of words that has especial meaning that is different from especial meaning of each separate word", for example, "under the weather" is an idiom meaning "slightly unwell or in low spirits." Most linguists have not dealt with the concept of idiomaticity (Makkia, 1972). According to this author, some distinguished linguists like Bloomfield, Harrish, and Chomsky have not introduced idiomaticity in their works, this explains that the reason behind not discussing idiomaticity is that this term is too broad. 
Again, Baker (2011) believes that idioms are frozen patterns of language which allow little or no variation in form and often carry meanings which cannot be deduced from their individual components. She supplies many examples of idioms in which meaning can be concluded by listener or reader by exclusively looking at the words. In this case, the idioms like "bury the hatchet" meaning "to become friendly again after a disagreement or a quarrel" and "the long and the shorter of it" meaning "the basic factor of the situation" are expressions whose meanings cannot be understood from the meaning of their singular elements.

\section{Strategies for translating idioms}

In this study, the researcher applied the translation strategies proposed by Baker (1992). These are the strategies for translating idiomatic expressions:

\section{Using an idiom of similar meaning and form}

This strategy involves using an idiom in the target language, which convey roughly the same meaning as that of the source language idiom and, in addition, consist of equivalent lexical items (Baker, 2011). In Persian, for example, we have:

\begin{tabular}{|c|c|c|c|}
\hline TL & My eye doesn't drink water & 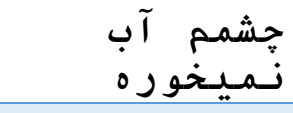 & SL \\
\hline $\mathbf{T L}$ & I am all ears & 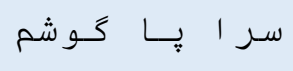 & $\mathrm{SL}$ \\
\hline $\mathbf{T L}$ & With tooth and nail & 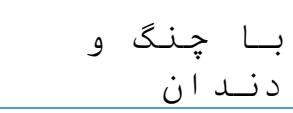 & SL \\
\hline
\end{tabular}

In this part, we have the meanings and forms of the source language idiom and exact equivalents for them.

\section{Using an idiom of similar meaning but dissimilar form}

According to Baker (2011) it is often possible to find an idiom or fixed expressions in the target language which has a meaning similar to that of the source idiom or expression, but which consists of different lexical items. For example: 


\begin{tabular}{|c|c|c|c|c|}
\hline TL & I'm speaking to the door so that the wall hears. & تـا & 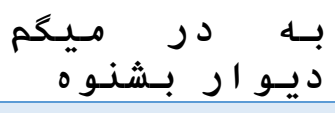 & SL \\
\hline TL & Out of sight, out of mind & انــــا & 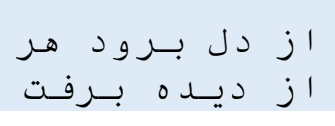 & SL \\
\hline TL & Would break the heart of stone & 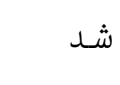 & دل سنـ آب مسى & SL \\
\hline
\end{tabular}

In these examples, we have the same meaning but different lexical item.

\section{Translation by paraphrase}

This is by far the most common way of translating idioms when a match cannot be found in the target language or when it is inappropriate in the target text because of differences in stylistic preferences of the source and target language (Aldahesh, 2013; Baker, 1992). Examples include:

\begin{tabular}{|c|c|c|c|}
\hline TL & $\begin{array}{l}\text { To take a donkey over the } \\
\text { roof }\end{array}$ & خـر بـالاى بـوم بـردن & SL \\
\hline TL & First things first & تـرن از نـان شب و اجب & SL \\
\hline $\mathbf{T L}$ & What is the noise all about? & كـردنم شــــهـ بـــــا & SL \\
\hline
\end{tabular}
idioms.

In this case, Translation by paraphrase could result in losing the stylistic impact of the

\section{Translation by omission}

As with single words, an idiom may sometimes be omitted altogether in the target text. Since it has no close equivalent in the target language, its meaning cannot be easily paraphrased, or for stylistic reasons (Baker, 1992). For example:

TL

TL
She offered a left-handed compliment

She has nerves of steel

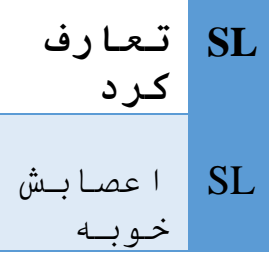


As it is observed here, translation has omitted some part of the idiom and changed the idiomatic expression into a non-idiomatic sentence.

\section{Methodology}

In this study, a researcher-made questionnaire was first given to ten assistant professors of English language department of Quchan Islamic Azad University. All participants had at least ten years of teaching experience and had published numerous scholarly articles in various English language fields. Finally, the results of the questionnaire showed that out of 200 terms and terms derived from Hedayat from the Persian novel, 97 can be considered as materials for further analysis. In this study, Baker strategies for translating idiomatic terms were used to evaluate translated idioms and conversations. These strategies were used in the form of a Likert questionnaire which was approved by the translator of this book (Bahrami). Of the 6 strategies mentioned, 4 are used in this research. Excel software was used to determine the number of responses to each item (strongly agree, agree, neutral, disagree and strongly disagree) and also show the percentage of each of these options in the form of a graph.

This is a descriptive study in which different terminology translation strategies have been studied. Data were collected from the novel Boof-e-Koor and its translation by Boof-e-Koor. To do this, the researcher first carefully studied the original text and highlighted the terms used. He then read the translated text to discover the distinctive strategies used by the translator. For this purpose, all Persian terms used were collected. To examine whether the selected terms are terms, the researcher used dictionaries such as the Longman Dictionary of Contemporary English (1995) and Dehkhoda Encyclopedia (1973). In addition, he searched the internet to make sure that the selected locations were idioms. Otherwise, they were excluded from the study.

Also, this research included 97 Persian terms and their English translations. According to these strategies, Persian terms and their English translations fall into different categories of techniques and strategies. The collected data were arranged and analyzed in the experimental part of the research. The researcher categorized each term according to Baker $(1992 ; 2011)$ strategies and tried to assess what problems arise in the process of translating the terms and what strategies are useful to deal with them.

As mentioned earlier, the data were entered into tables by Excel software. Because the researcher wanted to understand the type of translation strategies that the translator uses in translating terms, this study was conducted with a quantitative and qualitative approach. Baker's 
(1992) proposed strategies were considered as a theoretical framework in this study. The extracted data were classified and then analyzed to answer the research instruments.

\section{Results}

\section{Translation Strategies Applied in Translation of Idioms}

As mentioned before in the overview of this chapter, the idioms emerged in the Persian version of Boof-e-koor and their translation in the English version of the book. As classified, according to the strategy used, they were translated. The researcher analyzed the translation of idioms in terms of Baker's strategies. The idioms and their analysis were classified based on a specific strategy which was applied in transformation of the idioms from Persian in to English. The following are strategies and analyzed idioms that fall under Baker's (2011) strategies of Translation:

\section{Using an idiom of similar meaning and form}

Due to the challenging nature of the metaphorical problem, various theories have been proposed in connection with translatability, non-translatability, and various methods of metaphorical translation, especially in connection with Qur'an' verses (Rezvantalab \& Dabbagh, 2021). In this strategy, idiom is similar to its form and meaning, that is to say the idioms have similar meaning with their forms. According to Baker (1992), this strategy involves using an idiom in the target language which conveys roughly the same meaning as that of the source language idiom and, in addition, consists of equivalent lexical items. Analyzing the idiomatic expressions in Boof-e-koor and their English translations, the researcher found that the following idioms were used: 
Table 1

Using an idiom of similar meaning and form

\begin{tabular}{|c|c|}
\hline English translation & Persian idioms \\
\hline $\begin{array}{l}\text { The major things that i gave up painting } \\
\text { designs. }\end{array}$ & 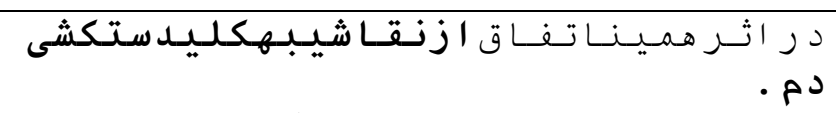 \\
\hline $\begin{array}{l}\text { There are certain sores in life, like a cancer } \\
\text { grows at the soul in solitude and diminish. }\end{array}$ & 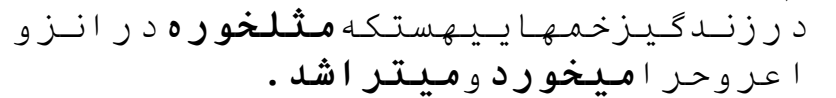 \\
\hline $\begin{array}{l}\text { I saw to camphor candles burning her } \\
\text { beside. }\end{array}$ & 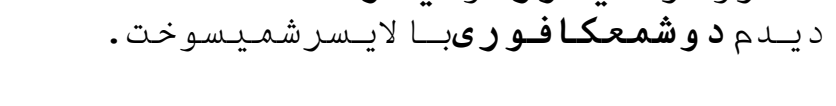 \\
\hline What a disgrace! I ran from the room. & 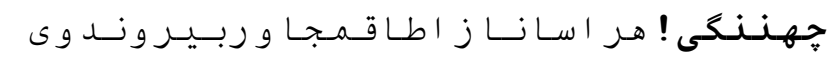 \\
\hline $\begin{array}{l}\text { Suddenly I realized that I had left the city } \\
\text { gate behind. }\end{array}$ & 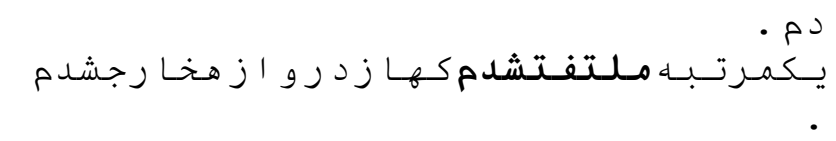 \\
\hline $\begin{array}{l}\text { Although Nanny's outward appearance had } \\
\text { changed, her thoughts had not. }\end{array}$ & 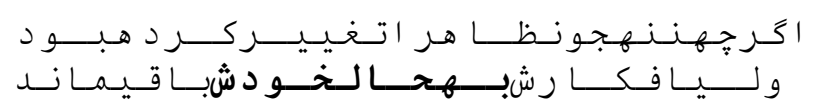 \\
\hline $\begin{array}{l}\text { The dead body with its protruding teeth } \\
\text { seemed to mock us. }\end{array}$ & 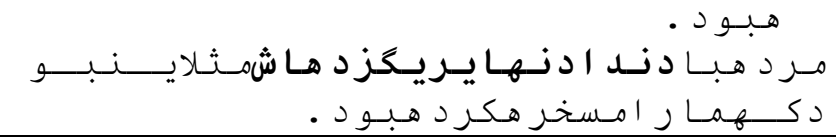 \\
\hline
\end{tabular}

For this part the translator used the similar meaning and form strategy to translate the intended idioms. In fact, the translator used their own expression to explain the messages of the sources text.

\section{Using and idiom of similar meaning but dissimilar form}

This strategy includes using and idiom in the target language which has the seam meaning in the source language, but its form is different. It replaces the translation of an idiom by an attentive and semantic equivalence without considering lexical items. For this type of strategy, the researcher found the following idioms in the book English translation of The Blind Owl: 
Table 2

Using an idiom of similar meaning but dissimilar form

\begin{tabular}{|c|c|}
\hline English translation & Persian idioms \\
\hline There was only thing that cheered me up. & ارى بيشتر بر ايم يك دلخوشى يا دلخوش كنك مانده بود. \\
\hline Was no longer in full control of myself. & در اين وقت از خودبيخودشد هبودم. \\
\hline $\begin{array}{l}\text { Walked all around our houses and the } \\
\text { neighborhood. }\end{array}$ & تمام اطر اف خانه مان را زيرياكردم. \\
\hline $\begin{array}{l}\text { In this adversity-stricken, miserable room, } \\
\text { itself a grave. } \\
\text { I was nothing of myself. }\end{array}$ & 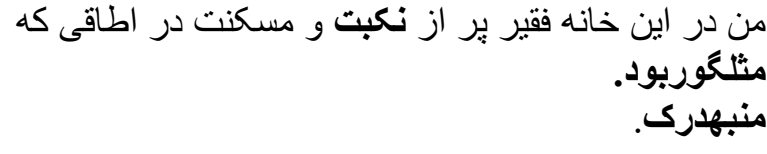 \\
\hline I looked around. Not a soul could be seen & دور خودم نشاه كردم دياريديدهنميشد. \\
\hline Like two peas in pod. & مثل سيبى كه از وسط نصف كرده باشند. \\
\hline
\end{tabular}

For this part translator used the similar meaning but dissimilar form in the translation text.

\section{Translation by paraphrase}

Paraphrase is the method of entering the meaning of something in other words. Baker (1992) believe that this is by far the most common way of translating idiom when, a match cannot be found in the target language or when it seems inappropriate to use idiomatic language in the target text by differences in stylistic preferences of the source and target language. There is feasibility that the nature of the idiom's meaning and stylistic quality in the source language might be lost. Concerning this strategy, the researcher found that the following idioms were used.

\section{Table 3}

\section{Translation by paraphrase}

\section{English translation}

God was too much for me.

On the last Wednesday of the year, she went eavesdropping.

No, the fear of death had dominated me and would not leave me alone.

Every time I turned my head in its direction, it stared right at me.

We all have lost our hearts I wish God would kill him and put him out of his misery.

\section{Persian idioms}

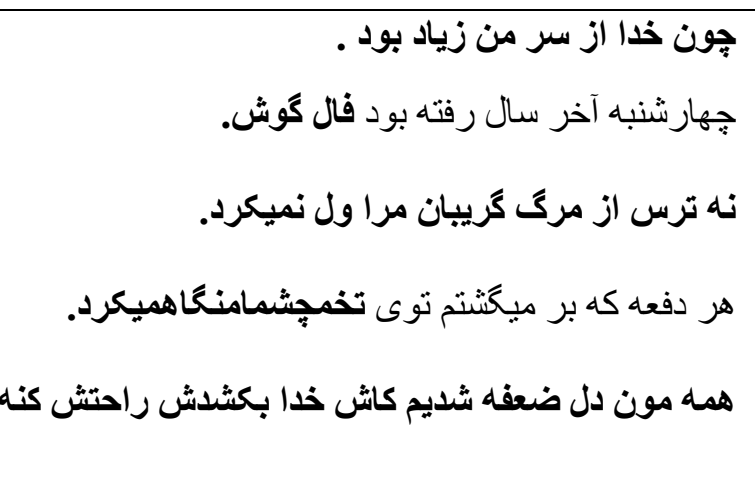


He must have found out last night.

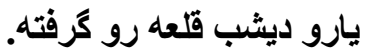

She said " take care of me "she put it, with a الا هم باجه كنجكاوى و دقتى مرا زير رو و به قول great deal of curiosity and attention.

خودش ثرو خشك ميكند.

For this part, the translator used paraphrase strategy for better understanding of the readers.

\section{Translation by omission}

As the case with single word, it is conceivable something to elide whole idiom in the target language. According to Baker (1992), as with single words and idiom may sometimes be admitted, altogether in the target text. This may be because it has no close match in the target language, it meaning cannot be easily paraphrased, or for stylistic reason. Translators use this strategy when an equivalent idiom is not found in the target language, so the original text and the translated version will not be parallel in terms of numbers of words. The following table represents the idioms translated based on omission strategy. There is no omission for this translation According to Fernando (1996), this idiom can be seen as pure one, because a reader or hearer cannot recognize the meaning of the idioms without referring to the context in which it was used. It seems that the translator was not sure about two meanings of idioms to be followed and presented in the target language. In the following, the collected data are analyzed through graph and figure.

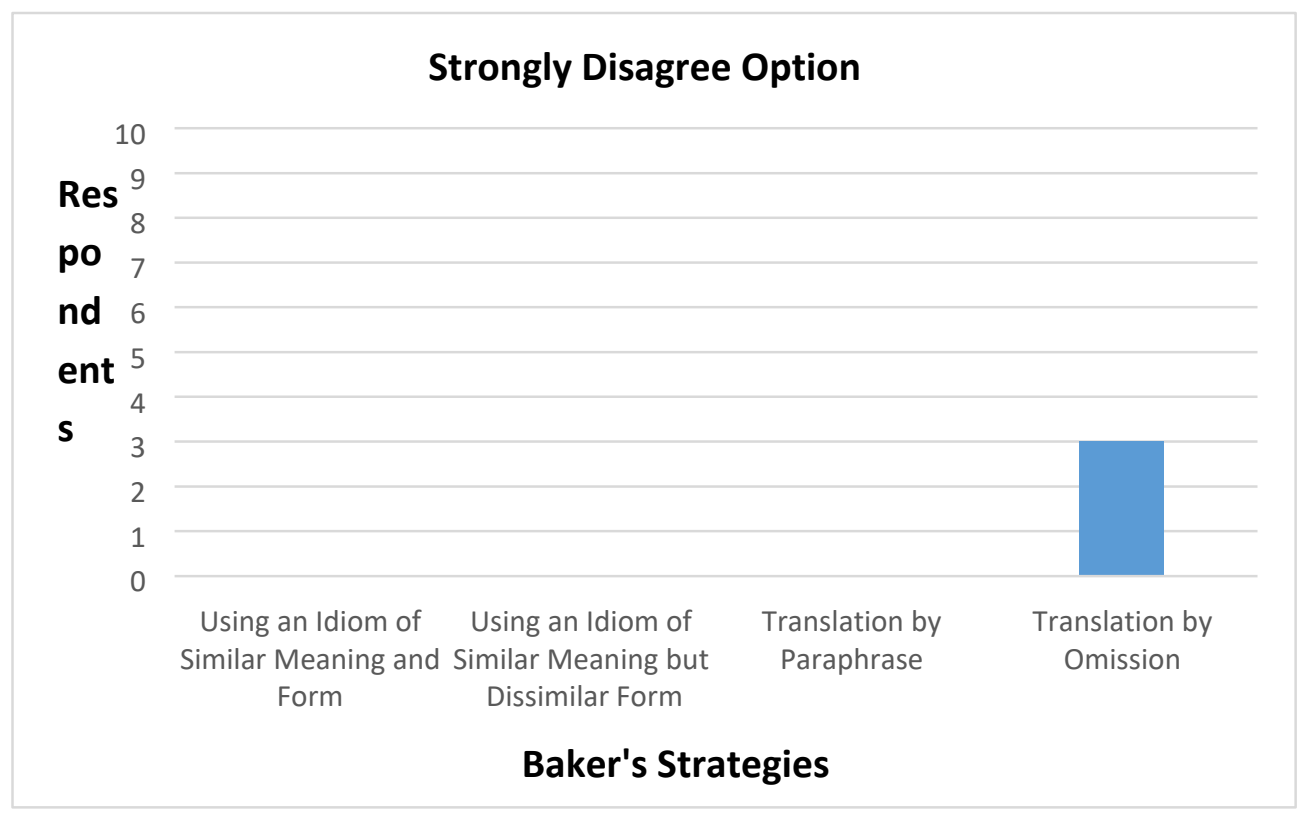

Figure 1. The "Strongly Disagree" answer to the questionnaire is based on Baker's Strategies 


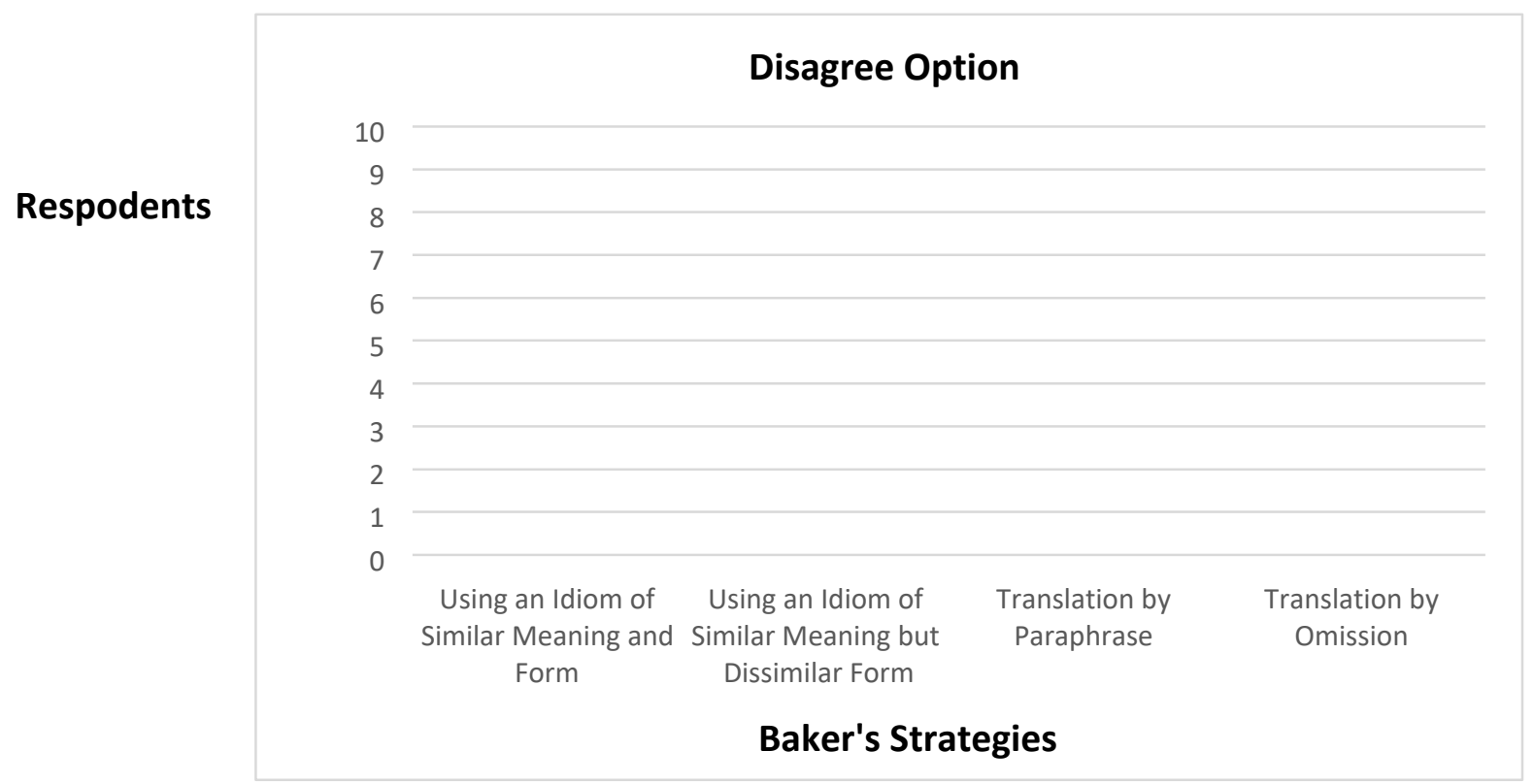

Figure 2."The Disagree" answer to the questionnaire is based on Baker's Strategies

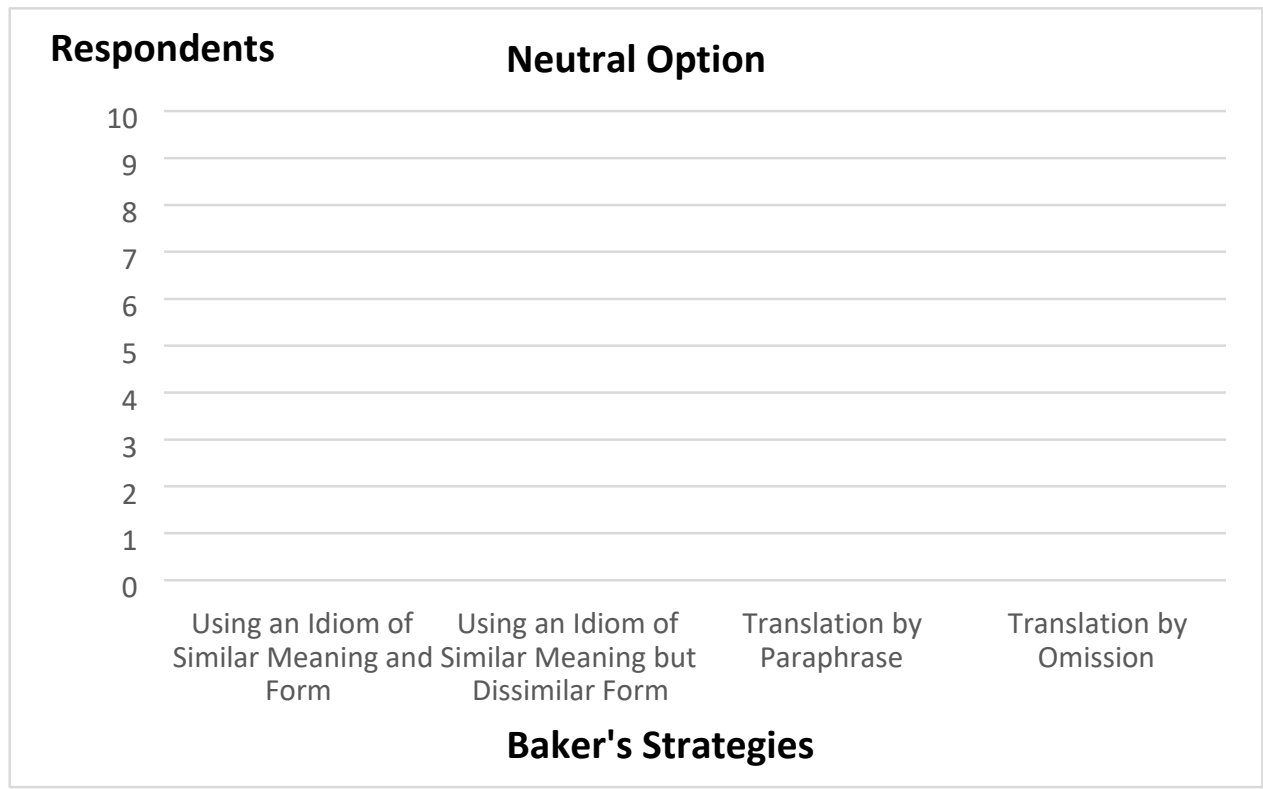

Figure 3. The "neutral" answer to the questionnaire is based on Baker's Strategies 

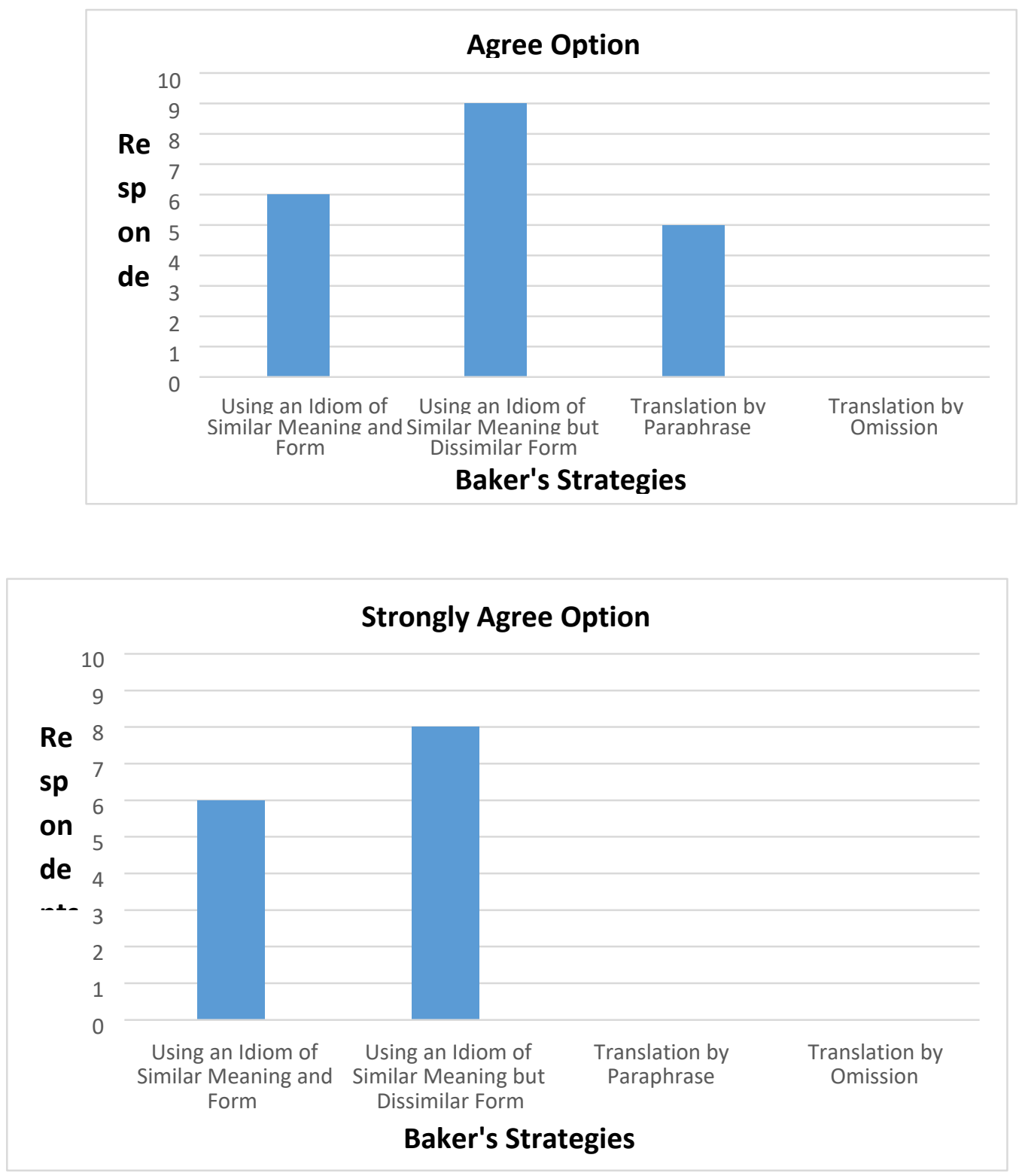




\section{Discussion}

In translating legal terms, it seems necessary to pay attention to points such as the transmission of semantic, textual and practical aspects. Some sacred texts, such as the Qur'an, contain precepts that are often legally binding, and since such precepts can be the source of some misunderstandings by readers, great care must be taken in translating them (Reza-Be-Afarin et al, 2019). Considering the important role of idioms in different languages, this study aimed at exploring translation strategies used in translation of idioms from Persian to English. In this case Sadraei (2010), examined the strategies used to translate idioms and proverbs that influenced the region. The aim of his study was to translate Persian idioms into English.. The researcher's doping was on the Persian idioms which included elements such as name of animals, plants, wind, rain, sun and so on, in their lexical structures. She collected several Persian idioms and proverbs which were mostly used in two provinces of Iran, Yazd and Mazandaran, and concluded that the most common strategy used in translation of idioms was using an idiom of similar meaning and form.

Analyzing the data, she witnessed that while in a specific region the name of an animal had been used in proverbs, in a different area the name of a plant had been mentioned to convey the 
same meaning. Based on Baker's strategies it was explained that the most appropriate strategy was using an idiom of similar meaning but dissimilar form. She also concluded that when the translator could not find any equivalent, she tried to account the meaning by paraphrasing (Sadraee, 2010).

One of the problems that every translator faces in translating from one language to another is the fixed terms and phrases of a language; Because they are part of the culture of a language. The story of Nun wa al-Qalam Jalal al-Ahmad is one of the few stories that is full of idioms and proverbs (Madvani, 2019).

\begin{tabular}{|l|l|}
\hline Difference & $\begin{array}{l}\text { The difference between this research and ongoing research is that ongoing } \\
\text { research is being used by translation by omission }\end{array}$ \\
\hline Similarity & $\begin{array}{l}\text { The similarity between this research and ongoing research is that ongoing research } \\
\text { is being used the similar meaning but dissimilar form }\end{array}$ \\
\hline
\end{tabular}

Although the art of translation has long been an obsolete method of language teaching, it is still used by language learners (Moinzadeh \& Masroor, 2015). The second research entitled "Translation procedure and problems of color idiomatic expressions in English and Persian: cultural comparisons in focus" was done by Ahmadi and Ketabi (2011). In this study, the researchers examined the applied translation strategies of color idiomatic expressions as well as cultural similarities and differences between color idioms in English and Persian. They collected 190 English and 90 Persian color idioms with their equivalents from bilingual dictionaries. The analysis of translation strategies of all data revealed that the following strategies were used in translating color idiom expressions (Ketabi, 2011):

1) using a non-idiomatic expression;

2) using an idiom of similar meaning and form;

3) using an idiom of similar meaning but dissimilar form;

4) literal translation;

5) paraphrasing; and

6) loan translation

The results of the study showed that the most frequently used translation strategies in both Persian and English data was translating by using non-idiomatic expressions of TL. In addition, 
loan translation was the least frequently used strategy applied. They also concluded that there were many cultural similarities and differences between color idiomatic expressions in English and Persian (Ketabi, 2011).

\section{Difference}

The difference between this research and ongoing research is that our research used the least frequency of translation by omission.

In this case, Homayounifar (2012) conducted a research study and investigated the strategies employed in translating idioms in Mohammad Ali Jamalzadeh's short stories. Jamalzadeh's collection of Persia short stories named Yeki Bud yeki Nabud has been translated into English by Heshmat Moyyad and Paul Sparkman (Homayounifar, 2012). The researcher collected 339 Persian idioms. The analysis of data revealed that following strategies were used in translating idiomatic expressions:

(1) paraphrasing

(2) using an idiom of similar meaning, but dissimilar from

(3) Literal translation

(4) Translation by omission

(5) Using an idiom of similar meaning and form

The results of the study showed that paraphrasing was the most frequently used strategy (Homayounifar, 2012).

\begin{tabular}{|l|l|}
\hline Difference & $\begin{array}{l}\text { The difference between this research and ongoing research is that ongoing } \\
\text { research used the strategy of similar meaning but dissimilar form }\end{array}$ \\
\hline
\end{tabular}

In a study by Farjad (2014) entitled "Translation strategies of English Idioms by EFL Lerner," the strategies employed in translating idiomatic expressions from English into the Persian were analyzed. The researcher used the strategies by Baker (1992) with a sample size of 60 intermediate level students. Analyzing the data revealed that using each strategy depends on many factors such as pervious knowledge of target and source idioms and the context of using the idioms (Baker, 2011). 
In their study entitled "Teaching Idiomatic Expressions in Language Classroom: like the Icing on the Cake", Winnberg and Rodriguez (2013) investigated the types of teaching approaches and methods to be used when teaching idiomatic expressions to learn English. The results showed that there are many different ways to better understand the meanings of idioms (Rodriguez,2013).

In a similar study Adelina and Dasterjedi (2011) applied the procedures and strategies of Baker (1992) in translating idiomatic expressions from English to Persian. They concluded that translators should focus on the pragmatic meanings of the idiomatic expressions rather than their literal meanings because such expressions cannot be understood from the individual words. There searchers also introduced that it is hard for translators to find adequate equivalent for some linguistic elements of the source language.

Moreover, a study by Ani (2013) found that English idioms in Agatha Christie's novel had been translated with the use of two strategies: translating idioms by one idiomatic expression in the TL, and changing a source text idiom by target text idiom. The researcher introduced the first strategy as "non-figurative expression" and the second one as "figurative expression".

In another study, the strategies that Persian translators applied to translate English idioms were investigated. For the purpose, the novel The Old Man and the Sea by Ernest Hemingway and its three translations by three different Iranian translators were selected as the corpus. To do so, English idioms of the novel and their Persian equivalents were extracted. In general, 69 idioms were found in the main source and its three selected corpora as a whole, among which 19 had been translated by paraphrasing, 8 by omission, 19 by the strategy of using an idiom of similar meaning but dissimilar form, and 23 by the strategy of using an idiom of similar meaning and form. After conducting the study and analyzing the data, it was witnessed that using an idiom of similar meaning and form had the highest frequency.

\section{Difference}

The difference between this research and ongoing research is that our research used strategy of similar meaning but dissimilar form. This strategy has more frequency compared to other strategies

Por his part, Rezvani (2012) conducted a study entitled "The analysis of the most used strategies of translating idioms in the translation of The Catcher in the Rye by Salinger." Two translations of the novel by two different Iranian translators were selected. Findings showed that 
the most frequently used strategy by the translators for translating idioms was using an idiom of similar meaning but dissimilar form" and the least used strategy was "Translation by omission".

Finally, the study conducted by Strakšiene (2009) discussed the strategies of translating idioms and highlighted the difficulties that translators face when translating idioms from English into Lithuania. It was concluded that paraphrasing strategy was the most preferred one in translating idioms from English into Lithuania to address the problem of non-equivalent.

\section{Difference}

The difference between this research and ongoing research is that our research used the strategy of similar meaning but dissimilar form. This frequency has more frequency compared to other strategies.

\section{Conclusion}

The purpose of this study was to investigate the strategies applied in translating Persian idioms in the novel The Blind $O w l$ by Hedayat into English. After collecting some Persian idioms in the ST and considering four strategies to cope with difficulties related to translating idiomatic expressions, the strategy of "translation by similar meaning but dissimilar form" was identified as the most frequently used strategy by the translator. As mentioned before, Baker expresses that the strategy of using an idiom with similar meaning but dissimilar form" preserves the semantic elements but not lexical items.

Another strategy was using similar meaning and form, which is used when there is a kind of cultural and social relationship between Persian and English. It was also witnessed that the strategy of translation by paraphrase is used when no equivalent is found for a source text idiom in the target language. In this regard, Baker argued that this popular way of translating idioms is used when a match cannot be found in the target language, or when it seems inappropriate to use an idiomatic language in the target text.

Moreover, these findings would be of interest to different scholars in such areas as translation, linguistics, sociolinguistics and pragmatics. In addition, the findings of the translation assessment of the corpus of this study might be useful in the realm of Translation Quality Assessment. Accordingly, the findings of the present study would help translators improve their level of pragmatic competency, at the minimum, in the area of politeness, which may result in improving the quality of translation. Furthermore, the outcomes of present study might help 
translation instructors to expose their student to some reliable sources of pragmatic information as to their mother tongue and the second-foreign language to be learned. It can also be inferred that this research can aid translating movies, idioms, and culture expressions, using equivalents from the TL in an effective and acceptable way.

\section{References}

Aldahesh, A. Y (2013). On idiomaticity in English and Arabic: Across-linguistic study. Academic Journals, 4 (2), 23-29. https://academicjournals.org/journal/JLC/article-full-textpdf/A00D3181989

Adelina, A. \& Dasterjedi, H. V. (2011). Translation of idioms: a hard task for the translation. Theory and Practice in Language Studies, 1 (7), 879-883. https://doi.org/10.4304/TPLS.1.7.879-883

Ahmadi, S. \& Ketabi, S. (2011). Translation procedure and problems of color idiomatic.

The Journal of International Social Research, 9-39. https://sosyalarastirmalar.com/cilt4/sayi17pdf/1diledebiyat/ahmadi_sahar_and_saeedketa bi.pdf

Akbar-Karkasi, M. (2020). New Research in the Field of Iranian Language and Literature. Tehran, Iran. https://civilica.com/doc/1041909/

Amini, R. (2021). A critical study of translation history in Iran, Critical Research Journal of Humanities Texts and Programs, 21 (1). https://civilica.com/doc/1207662/

Baker, M. (1992). In other words: A source on translation. London: Routledge.

Baker, M. (2011). In other words: A course book on translation. London: Routledge.

Bosiacka, A. J. (2018). Theoretical and logical prerequisites for legal translation, International Journal of language and law, 7. DOI:10.14762/j11.2018.047

Blidi, S. (2018). Linguistic and domain driven knowledge deficiency in legal translation. International Journal of Sciences and Research, 74 (3). DOI: 10.21506/j.ponte.2018.3.11.

Catford, J. C. (1965). A linguistic theory of translation: An essay on applied linguistic. London, England: Oxford University Press.

Ebrahimi, M. (2015). Taken a back by Saeedpour's "saboteurs" translation, 3rd International Conference on Applied Research in Language Studies, Tehran, Iran. https://civilica.com/doc/458005

Eghbali, M. (2020). An analysis of the implicit meanings of some words of the Holy Quran based on the analysis of lexical units and its reflection in contemporary translations. Quarterly Journal of Quranic Research, 25 (94). https://civilica.com/doc/1043521 
Fernando, C. (1996). Idioms and Idiomaticity. New York, USA: Oxford University Press.

Gholipour, L. (2018). Borrowed words in the translation of medical texts and approved equivalents of the Academy, Second International Conference on New Horizons in Humanities and Management, Tehran, Iran. https://civilica.com/doc/710719/

Ghorbani-Madwani, Z. (2019). A study of Majedeh Annani's translation of Jalal Al-Ahmad's Bread and Pen based on Baker's theory of equilibrium equation, Bi-Quarterly Journal of Translation Studies in Arabic Language and Literature, 9, 21. https://civilica.com/doc/1033619/

Good-Taste, M. \& Shafiee, S. (2021). An introduction to the status and status of oral description in Iran. Quarterly Journal of Language and Translation Studies, 54 (2), https://civilica.com/doc/1189311/

House, J. (2015). Translation quality assessment: past and present. http://www.translationindustry.ir/Uploads/Pdf/TranslationQualityAssess ment.pdf

Khani-Kalghaei, H., Osmani, A., \& Azizi, A. (2020). Semantics of the word forgery in the process of translation of the Qur'an (with emphasis on the translations of Ansarian, Khorramshahi, Fooladvand, Elahi Ghomshei and Makarem Shirazi). Third National Conference on Research Quranic, Tehran, Iran. https://civilica.com/doc/1046620

Kovecses, Z. (2010). Metaphor: A practical introduction. New York, USA: Oxford University Press.

Makkai, A. (1972). Idiom structure in English. The Hague, Netherlands: Mouton \& Co. N. V.

Manafi-Anari, S.; \& Ebrahimi, A.(2020). The role of religious beliefs in English translations of the holy Quran (by examining case verses in the translations of Al-Hilali and Mohsen Khan). Third National Conference on Quranic Studies, Tehran, Iran. https://civilica.com/doc/1046533/

Moon, R. (1998). Fixed expressions and idioms in English: A corpus-based approach. Oxford, England: Clarendon Press.

Moeinzadeh, S. N. \& Masroor, A. (2015). The effect of translating English terms on the auditory perception of Iranian students, Ormazd Research Journal, 8 (2). 16-22. https://civilica.com/doc/753232/

Moin D., Sharifi, S. \& Khanjan, A. (2016). Application of cultural filter in translation: case study of English translation by Moradi Kermani Carpet Weavers. Quarterly Journal of Language and Translation Studies, 49 (3). https://civilica.com/doc/722177/

Munday, J. (2012). Introducing translation studies: Theories and applications. London, England: Routledge

Pearson, L. T. (2009). Longman Advance Learner Dictionary. New York, USA: Pearson Ltd. 
Rezvantalab, Z. \& Dabbagh, E. (2021). A comparative study of translating metaphors from Surah Al-Baqarah into French from the perspective of Newmark strategies: a case study of Regis Blasher and Jacques Burke translations. Linguistics Quarterly, 13 (38), https://civilica.com/doc/1188329/

Sadeghi, B; \& Farjad, A. (2014). Translation strategies of English idioms by EFL learners. Language Learning and Applied Linguistic World, 6 (3), 247-259. https://pdfcoffee.com/finalversion6320pdf-pdf-free.html

Strakisiene, M. (2009). Analysis of idiom translation strategies from English into Lithuania, Kallbu Studijos, 1 (14), 13-19. https://www.kalbos.lt/zurnalai/17_numeris/04.pdf

Yaqub, M. O. (2014). Text-types, translation types and translation assessment: a case study of chapter 112 of the holy Quran in Rodwell, Al-Hilali and Khan's translation. International Journal of Humanities and Social Science. 48 (1). http://www.ijhssnet.com/journals/Vol_4_No_8_1_June_2014/25.pdf. 